\title{
Analisis Kepuasan Konsumen Terhadap Kualitas Produk dan Layanan Dengan Metode Importance Perfomance Analysis (Studi kasus Mie Rampok Jimbaran)
}

\author{
Mei Kurnia ${ }^{1}$, Amna Hartiati ${ }^{2}$, Ketut Satriawan ${ }^{2}$ \\ ${ }^{1}$ Mahasiswa Jurusan Teknologi Industri Pertanian, Fakultas Teknologi Pertanian Unud \\ ${ }^{2}$ Dosen Jurusan Teknologi Industri Pertanian, Fakultas Teknologi Pertanian Unud \\ E-mail: meykurnia53@yahoo.co.id ${ }^{1}$ \\ E-mail koresponden : amnahartiati@unud.ac.id ${ }^{2}$
}

\begin{abstract}
This study aims to know about the primary attributes at Mie Rampok Jimbaran to get the consumer satisfaction to know the grade of consumer satisfaction on product and service at Mie Rampok Jimbaran, and to choose which attributes should be the priority to be inproved by the company to achive the consumer satisfaction. The study was conducted at Mie Rampok Jimbaran. The Sample is 98 respondents used judgement sampling method. The data collected by distributed questionnaires and directly to respondents. The study using importance performance analysis (IPA) method. The result showed that the highest grade of cunsomer satisfaction for product was variant of product with the compatibility level of $102,11 \%$. The lowest grade of customer satisfaction for product was product quality assurance with the compatibility level of $86,18 \%$. The highest grade of customer satisfaction for service was interior design is unique with the compatibility level $101,01 \%$. The lowest grade of customer satisfaction for service was staff quick to treat consumer with the compatibility level of $88,97 \%$. The attributes that must have priority for product is product quality assurance, ingredients to used for product and product availability. The attributes that must have priority for service is the skilled staff, staff giving clear informations for consumer, staff quick to helping consumer and staff quick to treat consumer.
\end{abstract}

Keywords: consumer satisfaction, Importance Perfomance Analysis, product, service.

\section{PENDAHULUAN}

Pertumbuhan penduduk meningkat menyebabkan kebutuhan akan makanan juga mengalami peningkatan. Hal ini mempengaruhi beberapa pihak usahawan mengambil peluang di bidang penjualan makanan seperti restoran. Mie Rampok merupakan satu dari sekian banyaknya restoran makanan yang ada. Restoran ini menjual mie sebagai produk utamanya. Mie rampok bukan satu-satunya restoran mie yang menjadikan mie sebagai produk olahan utama sehingga menciptakan persaingan untuk mendapatkan pelanggan. Hasil wawancara dengan pihak mie rampok menjelaskan bahwa usahanya memiliki pesaing berat. Pesaing tersebut yang mengenalkan produk olahan mie pedas pertama kali di wilayah Bali dan menjadi fenomenal sehingga menciptakan produk tersebut menjadi tolak ukur konsumen terhadap produk olahan mie pedas. Fenomena ini mendorong pihak Mie Rampok untuk mengetahui tingkat penerimaan konsumen terhadap kualitas produk dan layanan dari Mie Rampok yaitu mengenai produk dan layanan yang mereka berikan apakah diterima dengan baik atau belum sesuai dengan harapan konsumen.

Kepuasan konsumen merupakan evaluasi spesifik terhadap penyedia produk dan pelayanan, sehingga kepuasan konsumen hanya dapat dinilai berdasarkan pengalaman yang pernah dialami saat proses pemberian produk dan pelayanan. Kepuasan konsumen dibidang produk dan pelayanan menjadi keharusan agar restoran tetap sukses. Persepsi konsumen terhadap kualitas produk dan layanan merupakan penilaian menyeluruh atas keunggulan suatu restoran. Salah satu cara membedakan sebuah restoran dengan 
pesaingnya adalah memberikan produk dan layanan dengan kualitas yang lebih tinggi dari pesaing secara konsisten.

Pratikto (2005) melakukan penelitian yang berjudul Analisis Tingkat Kepuasan Konsumen terhadap Pelayanan Restoran Famili Resto Cibubur. Teknik pemilihan sampel yang digunakan bersifat tidak acak atau non probability sampling. Atribut mutu yang dinilai responden paling penting pada setiap dimensi mutu adalah: ketersediaan menu yang dipesan untuk dimensi reliability; kesesuaian dalam hal rasa dan penampakan menu untuk dimensi assurance; kondisi peralatan makan dan tempat penyajian untuk dimensi tangible; kesediaan penyaji untuk menghargai dan melayani pelanggan atau tamu untuk dimensi empathy; serta kemampuan penyaji menata ulang tata letak menu di meja makan 15 untuk dimensi responsiveness. Atribut mutu yang dinilai responden paling memuaskan pada setiap dimensi mutu adalah: ketersediaan menu yang dipesan untuk dimensi reliability; kesesuaian dalam hal rasa dan penampakan menu untuk dimensi assurance; tata letak penyajian di meja makan untuk dimensi tangible; kesediaan penyaji untuk menghargai dan melayani pelanggan atau tamu untuk dimensi empathy; serta kecepatan penyaji menambah pesanan untuk dimensi responsiveness. Penelitian kepuasan konsumen sebelumnya pernah dilakukan oleh Maharani (2007) menganalisis Tingkat Kepuasan Pelanggan terhadap Mutu Pelayanan dan Mutu Produk Makanan di Restoran Kedai Sunda Cipayung Bogor. Berdasarkan hasil IPA, atribut yang dianggap penting dan memuaskan pelanggan yaitu kecepatan mengantarkan pesanan, kesesuaian pesanan dengan makanan yang disajikan, kebersihan peralatan makan (piring, gelas, sendok dan garpu), ketepatan dalam proses pembayaran, dan kenyamanan restoran.

Metode dalam pengukuran kepuasan konsumen diantaranya Structural Equation Modeling (SEM), Importance Performance Analysis (IPA), Costomer Satisfaction Index (CSI). Metode yang digunakan dalam penelitian ini adalah Importance Performance Analysis (IPA) karena memiliki beberapa kelebihan dibandingkan dengan metode lain. Kelebihan tersebut antara lain dapat menunjukkan atribut produk/jasa yang perlu ditingkatkan ataupun dikurangi untuk menjaga kepuasan konsumen, hasilnya relatif mudah diinterpretasikan, skalanya relatif mudah dimengerti, dan membutuhkan biaya yang rendah (Dian, 2014).

Tujuan penelitian adalah mengetahui atribut-atribut yang dianggap penting oleh konsumen demi tercapainya kepuasan konsumen, mengetahui tingkat kepuasan atau tingkat kesesuaian harapan konsumen terhadap produk dan pelayanan Jimbaran dan menentukan atribut-atribut apa yang perlu mendapatkan prioritas dari Mie Rampok berdasarkan tingkat kepentingan dan kinerja untuk memberikan kepuasan konsumen terhadap konsumennya.

\section{METODE PENELITIAN}

Penelitian dilaksanakan di Mie Rampok Jimbaran, Jl. Uluwatu 45xx Jimbaran, Bali. Waktu penelitian dilakukan dari bulan Juni-Oktober 2017. Jumlah responden yang dipilih berdasarkan Metode Slovin dengan tingkat kesalahan $10 \%$ adalah 98 orang dengan jumlah sampel minimum adalah lebih besar dari atau sama dengan $30(\mathrm{n} \geq 30)$. (Kerlinger dan Lee, 2000).

Uji reliabilitas dilakukan dengan menggunakan metode Cronbach Alpha. Alat ukur dikatakan reliable jika menggunakan koefisien alpha lebih besar dari 0,60. Dalam penelitian ini pengukuran validitas 
kuesioner menggunakan teknik Product Moment. Apabila r product moment lebih besar dari nilai korelasi pada tabel angka kritik nilai $\mathrm{r}$ berarti korelasi antara $\mathrm{X}$ dan $\mathrm{Y}$ adalah konsisten dan reliabel serta valid untuk digunakan (Saidani dan Arifin, 2012). Tingkat kepuasan konsumen diukur menggunakan teknik analisis kepentingan dan kinerja (importance performance analysis). Berdasarkan tingkat penilaian kepentingan dan kinerja maka dihasilkan tingkat kesesuaian antara tingkat kepentingan dan tingkat pelaksanaannya (Supranto, 2003). Unsur-unsur kepuasan konsumen akan dijabarkan dan dibagi menjadi empat bagian kedalam diagram cartesius (Supranto, 1997). Kuadran A dianggap penting oleh pelanggan, tetapi pada kenyataannya faktorfaktor ini belum sesuai dengan harapan pelanggan (tingkat kepuasan yang diperoleh masih rendah), yang masuk dalam kuadran ini harus ditingkatkan. Kuadran B dianggap penting oleh pelanggan, dan faktor-faktor yang dianggap pelanggan sudah sesuai dengan yang dirasakannya sehingga tingkat kepuasannya relatif lebih tinggi, yang masuk dalam kuadran ini harus tetap dipertahankan karena semua variabel ini menjadikan produk atau jasa unggul di mata pelanggan. Kuadran C dianggap kurang penting oleh pelanggan, dan pada kenyatannya kinerjanya tidak terlalu istimewa, yang termasuk dalam kuadran ini dapat dipertimbangkan kembali karena pengaruhnya terhadap manfaat yang dirasakan oleh pelanggan sangat kecil. Kuadran D dianggap kurang penting oleh pelanggan, dan dirasakan terlalu berlebihan, yang termasuk dalam kuadran ini dapat dikurangi agar perusahaan dapat menghemat biaya.

Tahapan penelitian yang dilakukan mulai dari survey pendahuluan untuk mencari permasalahan dan tujuan penelitian, kemudian penentuan dan penggolongan atribut-atribut kepuasan konsumen untuk produk dan layanan, serta penyusunan kuesioner. Setelah menyusun kuisioner, dilakukan penentuan populasi dan sampel dengan metode Slovin. Penelitian dilanjutkan dengan pengujian reliabilitas dan validitas terhadap kuesioner di Mie Kober Renon Denpasar Bali. Pengujian reliabilitas dan validitas ini sangat penting dilakukan karena bertujuan untuk mengetahui sejauh mana suatu alat ukur dapat dipercaya serta sejauh mana alat ukur dapat mengukur tingkat kepentingan konsumen dan tingkat kinerja perusahaan yang ingin diukur. Apabila setelah diuji kuesioner ternyata tidak reliabel dan tidak valid, maka dilakukan revisi terhadap kuesioner dan pengujian kembali. Apabila kuesioner yang telah diuji ternyata reliabel dan valid maka penelitian dilanjutkan ke tahap penyebaran kuisioner untuk penelitian utama. Data dikumpulkan dan dianalisis menggunakan program Statistical Product and Service Solutions (SPSS) dan Microsoft Excel. Setelah analisis data, akan didapatkan atribut-atribut yang dianggap penting, atribut prioritas serta tingkat kepuasan konsumen terhadap produk dan pelayanan.

\section{HASIL DAN PEMBAHASAN}

\section{Gambaran Umum Perusahaan}

Mie Rampok dengan konsep unik "Rumah Penjara" menyajikan makanan utama Mie Pedas dengan berbagai tingkat kepedasan dengan toping dimsum didukung minuman, makanan dan dessert kreasi sendiri yang bercita rasa terbaik tapi harga terjangkau. Segmentasi yang diambil yaitu kalangan anak muda. Selain makanan, mie rampok juga mendukung kedai dengan disain interior seperti penjara lengkap beberapa peralatan tahanan. Mie rampok pertama kali diperkenalkan oleh Yoyok Nurcahyo, usaha ini berada di bawah naungan CV Mbledos Group dan berdiri sejak September 2015 dengan menawarkan konsep kemitraan. 
Sampai saat ini, sudah ada 22 gerai di wilayah Indonesia diantaranya Surabaya (sebagai kota pendiri Mie Rampok), lalu Jakarta, Bandung, Jogja, Lampung, Makasar, Parung, Jember, Bali. Salah satu gerai yang dibuka di Bali yaitu Mie Rampok Jimbaran yang berlokasi di Jl. Uluwatu 45xx Jimbaran Bali, dibuka beberapa bulan lalu tepatnya sejak 12 September 2016 dari jam 12:00 Wita s/d 23:00 Wita. Mie Rampok menawarkan menu mie dengan berbagai tingkat kepedasan, ada 11 tingkat kepedasan yang bisa dipilih konsumen. Sebagai menu pendamping dihadirkan dimsum dengan berbagai pilihan topping, seperti pangsit goreng, pangsit nori. Mie rampok hingga saat ini hampir tidak pernah sepi pengunjung dengan rata-rata 4000 konsumen setiap bulannya.

\section{Analisis Reliabilitas dan Validitas}

Hasil uji reliabilitas kuesioner kepentingan produk didapatkan koefisien alpha $(\alpha)$ sebesar 0,633 dan untuk koefisien alpha $(\alpha)$ kuesioner kinerja produk didapatkan sebesar 0,733 sehingga bisa dikatakan tiap item pertanyaan pada kuesioner reliabel karena memiliki koefisien alpha $(\alpha)$ lebih besar dari 0,60 (Griethuijsen et al., 2014). Hasil uji reliabilitas kuesioner kepentingan pelayanan didapatkan koefisien alpha $(\alpha)$ sebesar 0,860 dan untuk koefisien alpha $(\alpha)$ kuesioner kinerja produk didapatkan sebesar 0,827 sehingga bisa dikatakan tiap item pertanyaan pada kuesioner reliabel karena memiliki koefisien alpha $(\alpha)$ lebih besar dari 0,60 (Griethuijsen et al., 2014).

Hasil uji validitas kuisioner tingkat kepentingan dan tingkat kinerja produk, didapatkan bahwa nilai $r$ setiap pernyataan pada kuesioner menunjukkan di atas nilai $r$ tabel $(\alpha=0,1)$ sebesar 0,301 dan hasil uji validitas kuesioner tingkat kepentingan dan tingkat kinerja pelayanan, didapatkan bahwa nilai $r$ setiap pernyataan pada kuesioner menunjukkan di atas nilai $r$ tabel $(\alpha=0,05)$ sebesar 0,301 . Hal ini berarti setiap pernyataan yang terdapat pada kuesioner valid untuk digunakan (Lodhita, 2014).

\section{Analisis Atribut yang Dianggap Penting oleh Konsumen}

Atribut yang dianggap penting oleh konsumen didapatkan dengan cara menghitung jumlah skor setiap atribut. Semakin besar jumlah skor setiap atribut maka bisa dikatakan semakin besar pula tingkat kepentingan atribut tersebut. Derajat kepentingan produk dan pelayanan dapat dilihat pada Tabel 1 dan 2.

Tabel 1. Penilaian Responden Terhadap Tingkat Kepentingan Atribut Kepuasan Konsumen Untuk Produk di Mie Rampok.

\begin{tabular}{cll}
\hline Peringkat & Atribut & Skor \\
\hline 1 & Rasa & 437 \\
2 & Bahan yang digunakan untuk pembuatan produk & 433 \\
3 & Jaminan mutu produk & 427 \\
4 & Ketersediaan Produk & 416 \\
5 & Penyajian makanan & 411 \\
6 & Harga Produk & 407 \\
7 & Inovasi Produk & 397 \\
8 & Jenis produk yang beragam & 380 \\
\hline
\end{tabular}

Ket : Skor maks $=490$ [skor tertinggi kuesioner (5) x jumlah responden (98)]

Skor min $=98$ [skor terendah kuesioner (1) $\mathrm{x}$ jumlah responden (98)] 
Berdasarkan hasil kuesioner tingkat kepentingan untuk produk, atribut dengan skor terbesar adalah rasa dengan total skor 437. Atribut dengan skor terkecil adalah Jenis produk yang beragam dengan total skor 380. Hal ini berarti rasa adalah hal yang dianggap paling penting oleh responden. Menurut Marsum (2005), meskipun rasa bersifat relatif namun produk dengan rasa yang enak dapat menjadi unsur penting dalam kualitas produk.

Tabel 2. Penilaian Responden Terhadap Tingkat Kepentingan Atribut Kepuasan Konsumen Untuk Pelayanan di Mie Rampok.

\begin{tabular}{clc}
\hline Peringkat & \multicolumn{1}{c}{ Atribut } & Skor \\
\hline 1 & Kebersihan fisik (ruang makan, peralatan,toilet dan fasilitas lain) & 437 \\
2 & Kesesuaian pesanan dengan yang dipesan konsumen & 424 \\
3 & Kemampuan berkomunikasi karyawan dengan konsumen baik & 418 \\
4 & Karyawan sigap dalam menangani keinginan konsumen & 417 \\
& Konsisten dalam memberikan pelayanan & \\
5 & Karyawan memberikan pelayanan yang memuaskan & 416 \\
6 & Pemahaman karyawan mengenai produk yang ditawarkan kepada konsumen & 414 \\
7 & Karyawan terlatih & 407 \\
8 & Pelayanan yang diberikan sudah sesuai dengan harapan konsumen & 406 \\
9 & Karyawan melayani konsumen dalam waktu yang cepat & 404 \\
10 & Karyawan sigap dalam membantu konsumennya & 403 \\
11 & Karyawan memberikan informasi yang jelas kepada konsumen & 400 \\
12 & Desain interior sangat menarik & 398 \\
13 & Penampilan karyawan rapi & 395 \\
14 & Penempatan produk yang rapi dan menarik & \\
15 & Pemahaman karyawan terhadap keinginan konsumen & 377 \\
16 & Memberan yang digunakan sangat menarik & 371 \\
17 & Menawarkan produk lainnya & 368 \\
\hline
\end{tabular}

Ket : Skor maks $=490$ [skor tertinggi kuesioner (5) x jumlah responden (98)]

Skor $\min =98$ [skor terendah kuesioner (1) x jumlah responden (98)]

Berdasarkan hasil kuisioner tingkat kepentingan untuk pelayanan, atribut dengan skor terbesar adalah kebersihan fisik (ruang makan, peralatan,toilet dan fasilitas lain), dengan total skor 437. Atribut dengan skor terkecil adalah menawarkan produk lainnya (17) dengan total skor 338. Menurut Tjiptono (2004), salah satu dimensi kualitas pelayanan adalah responsivitas yaitu kecepatan atau kesigapan para karyawan dalam melakukan pelayanan, hal ini menunjukkan bahwa hasil penilaian dari konsumen untuk tingkat kepentingan kualitas pelayanan telah sesuai dengan salah satu dimensi kualitas pelayanan yaitu kecepatan pelayanan.

\section{Analisis Tingkat Kinerja}

Analisis tingkat kinerja Mie Rampok dilakukan dengan cara menghitung skor penilaian setiap atribut sehingga diketahui penilaian konsumen terhadap kinerja Mie Kampok. Semakin besar skor yang didapat, maka semakin besar pula penilaian responden terhadap kinerja Mie Rampok. Derajat kinerja produk dan pelayanan dapat dilihat pada Tabel 3 dan 4. Berdasarkan hasil kuesioner tingkat kinerja untuk produk, atribut dengan skor terbesar adalah Inovasi Produk dengan total skor 394. Sedangkan atribut dengan skor terkecil adalah Jaminan Mutu Produk dengan total skor 368. Inovasi produk menurut Hurley and Hult dalam (Kusumo, 2006) mendefinisikan inovasi sebagai sebuah mekanisme perusahaan untuk beradaptasi dalam lingkungan yang dinamis, oleh karena itu perusahaan dituntut untuk mampu menciptakan pemikiran - 
pemikiran baru, gagasan-gagasan baru dan menawarkan produk yang inovatif serta peningkatan pelayanan yang memuaskan pelanggan.

Tabel 3. Penilaian Responden Terhadap Tingkat Kinerja Atribut Kepuasan Konsumen Untuk Produk di Mie Rampok.

\begin{tabular}{|c|c|c|}
\hline Peringkat & Atribut & Skor \\
\hline 1 & Inovasi Produk & 394 \\
\hline 2 & Rasa & 391 \\
\hline 3 & Jenis produk yang beragam & 388 \\
\hline 4 & Penyajian makanan & 385 \\
\hline 5 & Bahan yang digunakan untuk pembuatan produk & 382 \\
\hline 6 & Ketersediaan Produk & 375 \\
\hline 7 & Harga Produk & 373 \\
\hline 8 & Jaminan mutu produk & 368 \\
\hline
\end{tabular}

Ket : Skor maks $=490$ [skor tertinggi kuesioner (5) x jumlah responden (98)]

Skor $\min =98$ [skor terendah kuesioner (1) $\mathrm{x}$ jumlah responden (98)]

Berdasarkan hasil kuesioner tingkat kinerja untuk pelayanan, atribut dengan skor terbesar adalah desain interior sangat menarik dengan total skor 402. Sedangkan atribut dengan skor terkecil adalah karyawan menawarkan produk lainnya dengan total skor 332. Gregory (2004), menyatakan desain adalah suatu bentuk usaha yang membentuk hubungan antara suatu produk dengan situasi yang menimbulkan kepuasan pada pemakainya.

Tabel 4. Penilaian Responden Terhadap Tingkat Kinerja Atribut Kepuasan Konsumen Untuk Pelayanan di Mie Rampok.

\begin{tabular}{clc}
\hline Peringkat & \multicolumn{1}{c}{ Atribut } & Skor \\
\hline 1 & Desain interior sangat menarik & 402 \\
2 & Kesesuaian pesanan dengan yang dipesan konsumen & 395 \\
3 & Kebersihan fisik (ruang makan, peralatan,toilet dan fasilitas lain & 392 \\
4 & Pelayanan yang diberikan sesuai dengan harapan konsumen & 389 \\
& Pemahaman karyawan mengenai produk yang ditawarkan kepada konsumen & \\
5 & Karyawan melayani konsumen dalam waktu yang cepat & 386 \\
6 & Penempatan produk yang rapi dan menarik & 385 \\
7 & Karyawan memberikan pelayanan yang memuaskan & 384 \\
8 & Kemampuan berkomunikasi karyawan dengan konsumen baik & 382 \\
9 & Penampilan karyawan rapi & 381 \\
10 & Konsisten dalam memberikan pelayanan & 380 \\
11 & Karyawan sigap dalam membantu konsumennya & 374 \\
12 & Karyawan sigap dalam menangani keinginan konsumen & 371 \\
13 & Peralatan yang digunakan sangat menarik & 369 \\
& Karyawan memberikan informasi yang jelas kepada konsumen & \\
14 & Karyawan terlatih & 368 \\
15 & Memberikan perhatian dengan ramah & 359 \\
16 & Pemahaman karyawan terhadap keinginan konsumen & 358 \\
\hline
\end{tabular}

Ket : Skor maks $=490$ [skor tertinggi kuesioner (5) x jumlah responden (98)]

Skor $\min =98$ [skor terendah kuesioner (1) $\mathrm{x}$ jumlah responden (98)]

\section{Analisis Tingkat Kepuasan Konsumen Mie Rampok}

Skor kinerja dan skor kepentingan dapat membentuk kepuasan karena kepuasan merupakan kesesuaian antara kinerja perusahaan yang diterima konsumen dengan kepentingan atau harapan yang diinginkan konsumen (Ainy et.al. 2012). Tingkat kepuasan atau tingkat kesesuaian, jika persentase yang didapatkan antara 80-100\% maka dapat dikatakan hasil dari masing-masing atribut telah memenuhi 
kepentingan atau harapan dari konsumen namun masih perlu dilakukan perbaikan lagi, sedangkan jika persentase yang didapatkan lebih dari 100\% maka dapat dikatakan hasil dari atribut tersebut telah melebihi kepentingan atau harapan konsumen (Lodhita, 2014).

Tabel 5. Hasil penilaian responden terhadap tingkat kepentingan (Y) dan tingkat kinerja (X) serta tingkat kepuasan (TKi) untuk produk di Mie Rampok.

\begin{tabular}{clccccc}
\hline No & Atribut & $\mathrm{Xi}$ & $\bar{X}$ & $\mathrm{Yi}$ & $\bar{Y}$ & Tki \% \\
\hline 1 & Rasa & 391 & 3.99 & 437 & 4.46 & 89.47 \\
2 & Harga Produk & 373 & 3.81 & 407 & 4.15 & 91.65 \\
3 & Bahan yang digunakan untuk & 382 & 3.90 & 433 & 4.42 & 88.22 \\
& pembuatan produk & 388 & 3.96 & 380 & 3.88 & 102.11 \\
4 & Jenis produk yang beragam & 394 & 4.02 & 397 & 4.05 & 99.24 \\
5 & Inovasi Produk & 385 & 3.93 & 411 & 4.19 & 93.67 \\
6 & Penyajian makanan & 368 & 3.76 & 427 & 4.36 & 86.18 \\
7 & Jaminan mutu produk & 375 & 3.83 & 416 & 4.24 & 90.14 \\
8 & Ketersediaan Produk & & $\bar{X}=3.90$ & & $\bar{Y}=4.22$ & 92.59 \\
\hline
\end{tabular}

Berdasarkan Tabel 5 atribut yang memiliki tingkat kepuasan atau tingkat kesesuaian tertinggi adalah jenis produk yang beragam dengan tingkat kesesuaian sebesar 102,11\% yang berarti kinerja Mie Rampok melebihi harapan konsumen. Sedangkan atribut dengan tingkat kesesuaian terendah adalah Jaminan mutu produk dengan tingkat kesesuaian sebesar $86,18 \%$ yang berarti kinerja Mie Rampok sudah sudah mencapai kepentingan atau harapan konsumen namun masih perlu dilakukan perbaikan lagi. Keragaman produk merupakan kumpulan seluruh produk dan barang yang ditawarkan penjual tertentu kepada pembeli (Kotler, 2003). Menurut Asep (2005), kondisi yang tercipta dari ketersediaan produk dalam jumlah dan jenis yang sangan variatif sehingga menimbulkan banyaknya pilihan dalam proses belanja konsumen.

Tabel 6. Hasil penilaian responden terhadap tingkat kepentingan (Y) dan tingkat kinerja (X) serta tingkat kepuasan (TKi) untuk pelayanan di Mie Rampok.

\begin{tabular}{|c|c|c|c|c|c|c|}
\hline No & Atribut & $\mathrm{Xi}$ & $\bar{X}$ & $\mathrm{Yi}$ & $\bar{Y}$ & Tki \% \\
\hline 1 & Kebersihan fisik (ruang makan, peralatan,toilet dan fasilitas lain. & 392 & 4.00 & 437 & 4.46 & 89.70 \\
\hline 2 & Penampilan karyawan rapi & 381 & 3.89 & 395 & 4.03 & 96.46 \\
\hline 3 & Peralatan yang digunakan sangat menarik & 369 & 3.77 & 371 & 3.79 & 99.46 \\
\hline 4 & Desain interior sangat menarik & 402 & 4.10 & 398 & 4.06 & 101.01 \\
\hline 5 & Penempatan produk yang rapi dan menarik & 385 & 3.93 & 395 & 4.03 & 97.47 \\
\hline 6 & Pelayanan yang diberikan sudah sesuai dengan harapan konsumen & 389 & 3.97 & 406 & 4.14 & 95.81 \\
\hline 7 & Karyawan memberikan pelayanan yang memuaskan & 384 & 3.92 & 416 & 4.24 & 92.31 \\
\hline 8 & Karyawan melayani konsumen dalam waktu yang cepat & 386 & 3.94 & 404 & 4.12 & 95.54 \\
\hline 9 & Karyawan terlatih & 368 & 3.76 & 407 & 4.15 & 90.42 \\
\hline 10 & Karyawan memberikan informasi yang jelas kepada konsumen & 369 & 3.77 & 400 & 4.08 & 92.25 \\
\hline 11 & Karyawan cepat dan sigap dalam membantu konsumennya & 374 & 3.82 & 403 & 4.11 & 92.80 \\
\hline 12 & Karyawan cepat dan sigap dalam menangani keinginan konsumen & 371 & 3.79 & 417 & 4.26 & 88.97 \\
\hline 13 & Kesesuaian pesanan dengan yang dipesan konsumen & 395 & 4.03 & 424 & 4.33 & 93.16 \\
\hline 14 & $\begin{array}{l}\text { Pemahaman karyawan mengenai produk yang ditawarkan kepada } \\
\text { konsumen }\end{array}$ & 389 & 3.97 & 414 & 4.22 & 93.96 \\
\hline 15 & Konsisten dalam memberikan pelayanan & 380 & 3.88 & 417 & 4.26 & 91.13 \\
\hline 16 & Kemampuan berkomunikasi karyawan dengan konsumen baik & 382 & 3.90 & 418 & 4.27 & 91.39 \\
\hline 17 & Menawarkan produk lainnya & 332 & 3.39 & 338 & 3.45 & 98.22 \\
\hline 18 & Memberikan perhatian secara personal dengan ramah & 359 & 3.66 & 368 & 3.76 & 97.55 \\
\hline \multirow[t]{2}{*}{19} & Pemahaman karyawan terhadap keinginan konsumen & 358 & 3.65 & 377 & 3.85 & 94.96 \\
\hline & & & $\bar{X}=3.85$ & & $\bar{Y}=4.08$ & 94.35 \\
\hline
\end{tabular}


Berdasarkan Tabel 6 atribut yang memiliki tingkat kepuasan atau tingkat kesesuaian tertinggi adalah desain interior sangat menarik dengan tingkat kesesuaian sebesar 101,01\% yang berarti kinerja Mie Rampok melebihi harapan konsumen. Sedangkan atribut dengan tingkat kesesuaian terendah adalah karyawan cepat dan sigap dalam menangani keinginan konsumen dengan tingkat kesesuaian sebesar $88,97 \%$ yang berarti kinerja Mie Rampok sudah mencapai kepentingan atau harapan konsumen namun masih perlu dilakukan perbaikan lagi. Menurut Tjiptono (2006), desain dan tata letak fasilitas jasa erat kaitannya dengan pembentukan persepsi pelanggan. Sejumlah tipe jasa, persepsi yang terbentuk dari interaksi antara pelanggan dengan fasilitas berpengaruh terhadap kualitas jasa tersebut di mata pelanggan.

\section{Kepuasan Konsumen untuk Kualitas Produk}

1. Kuadran A

Atribut-atribut yang berada di kuadran A merupakan atribut yang dianggap penting oleh responden, namun kinerja yang diterima dalam pelaksanaannya dinilai kurang oleh konsumen. Atribut-atribut tersebut adalah jaminan mutu produk (atribut no.7), bahan yang digunakan untuk pembuatan produk (atribut no.3) dan ketersediaan produk (atribut no. 8). Hasil dari kuadran ini Mie Rampok harus meningkatkan kinerja atribut-atribut yang berada di kuadran ini karena belum maksimal agar mencapai harapan dari konsumen sehingga tercapai kepuasan konsumen yang diinginkan.

2. Kuadran B

Atribut-atribut yang berada di kuadran B merupakan atribut yang dianggap penting oleh responden dan kinerja yang diterima dalam pelaksanaannya dinilai sudah sesuai dengan harapan konsumen. Atributatribut tersebut adalah rasa (atribut no.1) Hasil dari kuadran ini Mie Rampok sudah melaksanakan atrtbutatribut tersebut dengan baik sehingga tercapai kepuasan konsumen.

3. Kuadran C

Atribut-atribut yang berada di kuadran $\mathrm{C}$ merupakan atribut yang dianggap kurang penting oleh responden dan kinerja yang diterima dalam pelaksanaannya juga biasa saja. Atribut-atribut tersebut adalah harga produk (atribut no.2). Hasil dari Kuadran ini Mie Rampok harus meningkatkan kinerja dari atributatribut ini agar tercapai kepuasan dari konsumen.

4. Kuadran D

Atribut-atribut yang berada di kuadran D merupakan atribut yang dianggap kurang penting oleh responden namun kinerja yang diterima dalam pelaksanaannya sudah sangat baik. Atribut-atribut tersebut adalah jenis produk yang beragam (atribut no. 4), inovasi produk (atribut no.5) dan penyajian makanan (atribut no. 6). Hasil dari kuadran ini Mie Rampok harus mempertahankan kinerja dari atribut-atribut ini namun jangan terlalu berlebihan dalam pelaksanaannya. 


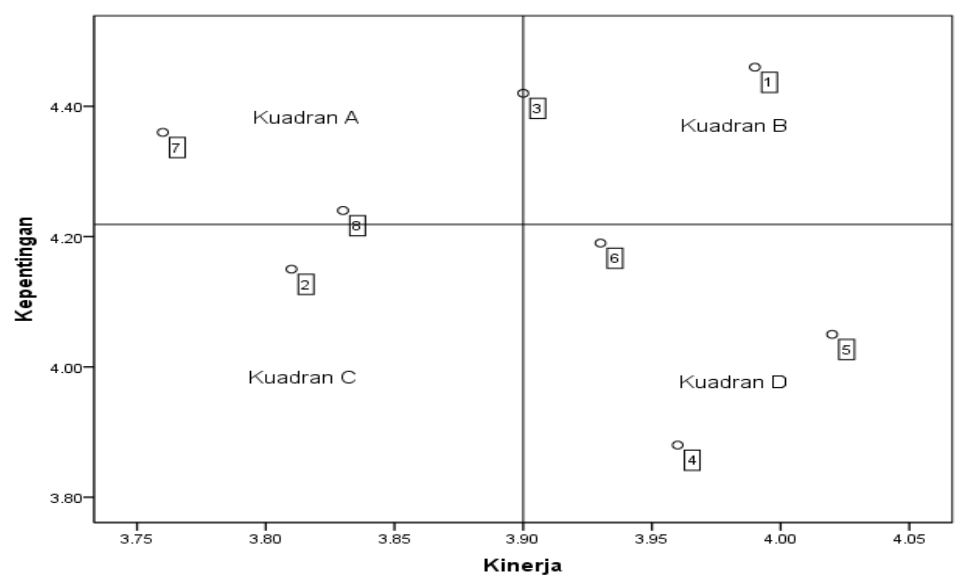

Gambar 1. Diagram Kartesius untuk kualitas pelayanan.

\section{Kepuasan Konsumen untuk Kualitas Pelayanan}

1. Kuadran A

Atribut-atribut yang berada di kuadran A merupakan atribut yang dianggap penting oleh responden. Namun kinerja yang diterima dalam pelaksanaannya dinilai kurang oleh konsumen. Atribut-atribut tersebut adalah Karyawan terlatih (atribut no.9), Karyawan sigap dalam membantu konsumennya (atribut no.11) dan Karyawan sigap dalam menangani keinginan konsumen (atribut no. 12). Hasil dari Kuadran ini Mie Rampok harus meningkatkan kinerja atribut-atribut yang berada di kuadran ini karena belum maksimal agar mencapai harapan dari konsumen sehingga tercapai kepuasan konsumen yang diinginkan.

\section{Kuadran B}

Atribut-atribut yang berada di kuadran B merupakan atribut yang dianggap penting oleh responden dan kinerja yang diterima dalam pelaksanaannya dinilai sudah sesuai dengan harapan konsumen. Atributatribut tersebut adalah kebersihan fisik (ruang makan, peralatan,toilet dan fasilitas lain (atribut no.1), pelayanan yang diberikan sesuai dengan harapan konsumen (atribut no.6), karyawan memberikan pelayanan yang memuaskan (atribut no.7), karyawan melayani konsumen dalam waktu yang cepat (atribut no.8), kesesuaian pesanan dengan yang dipesan konsumen (atribut no.13), pemahaman karyawan mengenai produk yang ditawarkan kepada konsumen (atribut no.14), konsisten dalam memberikan pelayanan (atribut no.15)dan kemampuan berkomunikasi karyawan dengan konsumen baik (atribut no.16). Hasil dari kuadran ini Mie Rampok sudah melaksanakan atribut-atribut tersebut dengan baik sehingga tercapai kepuasan konsumen.

3. Kuadran C

Atribut-atribut yang berada di kuadran $\mathrm{C}$ merupakan atribut yang dianggap kurang penting oleh responden dan kinerja yang diterima dalam pelaksanaannya juga biasa saja. Atribut-atribut tersebut adalah: Peralatan yang digunakan sangat menarik (atribut no.3), Karyawan memberikan informasi yang jelas kepada konsumen (atribut no.10), Menawarkan produk lainnya (atribut no.17), Memberikan perhatian dengan ramah (atribut no.18) dan Pemahaman karyawan terhadap keinginan konsumen (atribut no.19). Hasil dari kuadran ini Mie rampok harus meningkatkan kinerja dari atribut-atribut ini agar tercapai kepuasan konsumen. 


\section{Kuadran D}

Atribut yang berada di kuadran D merupakan atribut yang dianggap kurang penting oleh responden namun kinerja yang diterima dalam pelaksanaannya sudah sangat baik. Atribut tersebut adalah Penampilan karyawan rapi (atribut no.2), Desain interior sangat menarik (atribut no.4) dan Penempatan produk yang rapi dan menarik (atribut no.5). Hasil dari kuadran ini Mie Rampok harus mempertahankan kinerja dari atributatribut ini namun jangan terlalu berlebihan dalam pelaksanaannya.

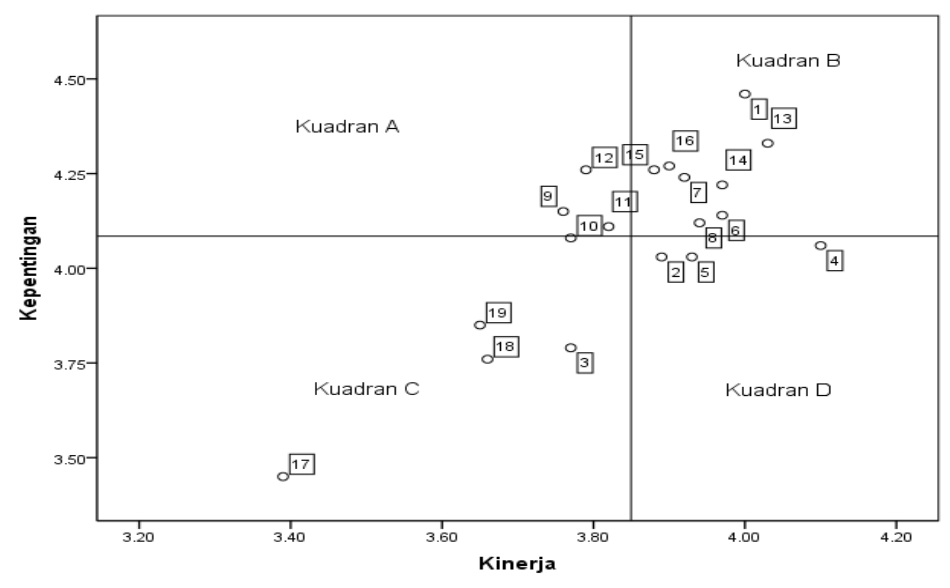

Gambar 2. Diagram Kartesius untuk kualitas pelayanan.

\section{KESIMPULAN DAN SARAN}

\section{Kesimpulan}

Berdasarkan analisis yang telah dilakukan sebelumnya, dapat disimpulkan beberapa hal sebagai berikut :

1. Atribut-atribut yang dianggap penting oleh konsumen untuk kualitas produk adalah (1) rasa, (2) jaminan mutu produk, (3) jenis produk yang beragam dan (4) ketersediaan produk. Sedangkan untuk kualitas pelayanan adalah (1) kebersihan fisik (ruang makan, peralatan, kebersihan toilet dan fasilitas lain), (2) pelayanan yang diberikan sudah sesuai dengan harapan konsumen, (3) Karyawan memberikan pelayanan yang memuaskan, (4) Karyawan melayani konsumen dalam waktu yang cepat, (5) karyawan terlatih, (6) Karyawan memberikan informasi yang jelas kepada konsumen, (7) Karyawan sigap dalam membantu konsumennya, (8) Karyawan sigap dalam menangani keinginan konsumen, (9) Kesesuaian pesanan dengan yang dipesan konsumen, (10 Pemahaman karyawan mengenai produk yang ditawarkan kepada konsumen, (11) Konsisten dalam memberikan pelayanan dan (12) Kemampuan berkomunikasi karyawan dengan konsumen baik.

2. Atribut-atribut yang memiliki tingkat kepuasan atau tingkat kesesuaian tertinggi untuk kualitas produk adalah jenis produk yang beragam dengan tingkat kesesuaian sebesar 102,11\% dan atribut dengan tingkat kesesuaian terendah adalah jaminan mutu produk dengan tingkat kesesuaian sebesar 86,18\%, Sedangkan untuk tingkat pelayanan adalah Desain Interior Sangat Menarik dengan tingkat kesesuaian sebesar $101,01 \%$ dan atribut dengan tingkat kesesuaian terendah adalah Karyawan cepat dan sigap dalam menangani keinginan konsumen dengan tingkat kesesuaian sebesar 88,97\%. 
3. Atribut-atribut yang perlu mendapatkan prioritas atau perhatian lebih untuk diperbaiki agar mencapai kepuasan konsumen untuk kualitas produk adalah jaminan mutu produk, bahan yang digunakan untuk pembuatan produk, dan ketersediaan produk. Sedangkan untuk kualitas pelayanan adalah Karyawan terlatih, karyawan memberikan informasi yang jelas kepada konsumen, Karyawan sigap dalam membantu konsumennya dan Karyawan sigap dalam menangani keinginan konsumen.

\section{Saran}

Saran dari penelitian ini yaitu perlu dilakukannya perbaikan oleh pihak Mie Rampok terhadap atribut-atribut kualitas produk dan kualitas pelayanan yang berada pada kuadran A. perbaikan kuadran A kualitas produk yaitu memberikan informasi bahan-bahan yang digunakan untuk pembuatan produk yang terjamin dan bermutu serta ketersediaan produk agar saat konsumen membeli masih tersedia. Perbaikan kuadran A kualitas produk yaitu diagram kartesius agar dapat mencapai kepuasan konsumen diantaranya untuk kualitas produk yaitu bahan yang digunakan untuk pembuatan produk, jaminan mutu produk, ketersediaan produk dan untuk kualitas pelayanan yaitu meningkatkan kualitas karyawan menjadi lebih baik serta sigap dalam membantu dan menangani konsumen.

\section{DAFTAR PUSTAKA}

Ainy, A. Misnaniarti, dan Fajar, N.A. 2012. Importance Performance Analysis Pelayanan Jaminan Sosial Kesehatan di Puskesmas Swakelola Pembina. Jurnal Kesehatan Masyarakat Nasional. 07 (3) : 105 110.

Dian, L. 2014. Analisis Persepsi Konsumen Menggunakan Metode Importance Performance Analysis Dan Customer Satisfaction Index. Jurnal Industri. 04(2) : 74 - 81.

Griethuijsen, R. A. L. F., Eijck, M. W., Haste, H., Brok, P. J., Skinner, N. C., Mansour, N., et al. (2014). Global patterns in students' views of science and interest in science. Research in Science Education, 45 (4):581-603.

Kerlinger, F. N \& Lee, H.B. 2000. Foundation of Behavioral Research (edisi terjemahan). Hartcourt College Publisher. New York.

Lodhita, H. E. 2014. Analisis Pengaruh Kualitas Pelayanan Terhadap Kepuasan Konsumen Menggunakan Metode IPA (Importance Performance Analysis) dan CSI (Customer Satisfaction Index) Studi Kasus pada Toko Oen, Malang. Skripsi. Jurusan Teknologi Industri Pertanian. Fakultas Teknologi Pertanian. Universitas Brawijaya.

Maharani, D.S. 2007. Analisis Tingkat Kepuasan Pelanggan terhadap Mutu Pelayanan dan Mutu Produk Makanan di Restoran Kedai Sunda Cipayung Bogor. Skripsi. Program Ekstensi Manajemen Agribisnis, Fakultas Pertanian. Institut Pertanian Bogor.

Pratikto, S.B. 2003. Analisis Tingkat Kepuasan Konsumen terhadap Pelayanan Restoran Famili Resto Cibubur. Skripsi. Departemen Ilmu-Ilmu Sosial Ekonomi Pertanian. Fakultas Pertanian. Institut Pertanian Bogor.

Saidani, B. dan Arifin, S. 2012. Pengaruh Kualitas Produk dan Kualitas Layanan Terhadap Kepuasan Konsumen dan Minat Beli pada Ranch Market. Jurnal Riset Manajemen Sains Indonesia (JRMSI).03 (01) : 1-22. 
Supranto, J.M.A. 1997. Pengukuran Tingkat Kepuasan Pelanggan Untuk Menaikkan Pangsa Pasar. PT. Rineka Cipta. Jakarta.

Supranto, J. 2003. Metode Riset. PT Asdi Mahastya. Jakarta 